\title{
THE CONSEQUENCES OF SHADOW ECONOMY AND CORRUPTION ON TAX REVENUE PERFORMANCE IN NIGERIA
}

\author{
Cordelia Onyinyechi Omodero* \\ "Michael Okpara" University of Agriculture, Umudike, Umuahia, Abia State, Nigeria, E-mail: \\ cordeliaomodero@yahoo.com
}

(Received: February 2019; Accepted: April 2019; Published: August 2019)

\begin{abstract}
Shadow economy and corruption are the two harmful activities that do not work in the favour of tax revenue performance. As a result it renders an effective government incapacitated and unable to carry out its social responsibilities. This study considers the effect of the informal economy and graft on tax revenue performance in Nigeria using secondary data that cover a period from 1996 to 2018. This period has been covered by the corruption perception index captured by the Transparency International for Nigeria. Despite the theoretical approaches available in measuring the size of the shadow economy, the ordinary least squares technique is specifically used to perform the multi-regression analysis to arrive at the empirical results which indicate that both the shadow economy and corruption have negative influences on tax revenue performance in Nigeria, although the negative impact of corruption on tax revenue is more robust and significant. Thus, the study suggests among others that the government should step up action against corruption and also address the root causes of shadow economy in order to make the participants of the informal sector willing to formalize their businesses and voluntarily comply with tax payment obligations.
\end{abstract}

Keywords: Shadow economy, corruption, tax revenue, government, Nigeria.

JEL Codes: O17, H20, D73

\section{Introduction}

Shadow economy and corruption have a common association and the existence of both of them in an economy appears to be a natural phenomenon. In other words, it is assumed that one cannot be present without the existence of the other. Shadow economy comprises all unregistered economic activities and income which contribute to the formally perceived Gross National Product (Chen \& Schneider,

\footnotetext{
* Corresponding author: Cordelia Onyinyechi Omodero. E-mail: cordeliaomodero@yahoo.com

Copyright @ 2019 The Author(s). Published by VGWU Press

This is an Open Access article distributed under the terms of the Creative Commons Attribution License - Non Commercial - NoDerivs License (http://creativecommons.org/licenses/by-nc-nd/3.0/) which permits unrestricted use, distribution, and reproduction in any medium, provided the original author and source are credited.
}

64 Sciendo Studia Universitatis "Vasile Goldis" Arad. Economics Series Vol 29 Issue 3/2019 ISSN: 1584-2339; (online) ISSN: $2285-3065$

Web: publicatii.uvvg.ro/index.php/studiaeconomia. Pages $64-79$ 
Omodero, C.O., (2019)

The consequences of shadow economy and corruption on tax revenue performance in Nigeria

2018). Shadow economy also refers to legal products and services that are hidden from the public authorities (Putnins \& Sauka, 2014). Corruption is cankerworm that depletes the fabrics of an economy and reduces a nation's integrity before the international community. Borlea, Achim and Miron (2017) refer to shadow economy and corruption as two harmful undertakings that jointly undermine democratic governance, legal framework and economic advancement. Although it is believed that corruption enhances economic growth especially in evolving countries like Nigeria where there is obvious weak regulatory structure and corruption helping to eliminate bureaucracy and accelerate business transactions, yet corruption has inbuilt qualitative destructive features that prevent real economic progress of a nation. In the same manner, it has been established that shadow economy contributes 65 percent of Nigeria's GDP (International Monetary Fund, 2017) due to high rate of unemployment, corruption and self-employment. Bologna (2015) asserts that shadow economy and corruption complement each other and so, the bigger the size of the underground economy, the higher the rate of corruption.

According to Petrescu (2016) people who carry out non-criminal activities in the informal sector usually find it difficult to switch to the formal sector. Those that engage into criminal activities during sanctions, also reject job opportunities in the official labor market even when the sanctions have been eliminated (Petrescu, 2016). The scenario is such that the informal workers underrate the importance of education and do not invest in their own education and that of their children because they have the understanding that the informal labor market offers jobs with little or no formal education (Petrescu, 2016). Despite the numerous benefits attributable to shadow economy and corruption, the truth is that shadow economy is the major cause of tax evasion which reduces government revenue. When government revenue decreases due to unreported incomes, then the government will be financially handicap and there will be insufficient fund to provide public goods and services (Hassan, 2017). The existence of underground economy may not necessarily have an adverse effect on the economies where the activities are prevailing, but the governments of those countries incur huge tax revenue losses and most times the labor regulations are violated (Nchor \& Konderla, 2016).

On the other hand, if taxpayers notice that corruption is prevailing in a country, they will lose confidence in the government and may be unwilling to perform their civic responsibility of paying taxes (Bird, MartinezVasquez \& Torgler, 2008). Corruption has a negative influence on tax administration and audits as well as the credibility of the institutions, hence following the level of corruption in a country, taxpayers are motivated to engage in informal sector in order to evade tax (Hunady \& Orviska, 2015). Besides, Aruba (2010) posits that the decline in citizens' trust in their government is one of the consequences of corruption evident in lack of 
Omodero, C.O., (2019)

The consequences of shadow economy and corruption on tax revenue performance in Nigeria

transparency and selfish acts of government officials. However, the challenge of tax morality enhances corruption (Ogunc \& Yilmaz, 2000) and the situation will usually have a negative influence on tax revenue and economic progression (Ivanyna, Moumouras \& Rangazas, 2016). The reason why many businesses choose to remain informal might not only be to evade tax, but rather, the complex tax system, regulation burdens and the costs of formalization of businesses that are less economical (Joshi, Prichard \& Heady, 2014). Shadow economy is usually promoted by tax system imperfections, inefficient public sector and strictly regulated labor market (Gaspareniene, Remeikiene \& Heikkila, 2016).

\subsection{Objective of the study}

This study aims at establishing the effect of shadow economy and corruption on tax revenue performance in Nigeria. The study seeks to pursue the following specific objectives:

1. To determine the effect of shadow economy on tax revenue in Nigeria.

2. To assess the impact of corruption on tax revenue in Nigeria.

\subsection{Research hypotheses}

In order to achieve the above research objectives this study is guided by the following hypotheses:

Ho1: Shadow economy does not have significant effect on tax revenue in Nigeria.

Ho2: Corruption does not exert any significant influence on tax revenue in Nigeria.

\section{Literature review}

\subsection{Theoretical approaches in measuring shadow economy}

Shadow economy is measured directly and indirectly. The direct approach involves the use of survey and tax audit.

\subsubsection{Direct approach}

The direct approach involves using survey and tax audit to establish the size of the shadow economy. The survey method is often confronted with the risk of miscalculation of the total size of the shadow economy due to lack of credibility of the feedbacks and sometime zero response from the respondents owing to the delicate nature of the subject (Putnins \& Sauka, 2015). In Nigeria, tax audit is usually carried out by the Federal Inland Revenue Service (FIRS) and State Board of Internal Revenue (SBIR) depending on the type of tax the audit is meant for. However, the two bodies, like in other countries embark on tax audit to establish the size of shadow economy through the level of tax evasions the audit exercise will reveal. To some extent, tax audit usually reveals undeclared taxable income

66 Studia Universitatis "Vasile Goldis" Arad. Economics Series Vol 29 Issue 3/2019 ISSN: 1584-2339; (online) ISSN: $2285-3065$

Web: publicatii.uvvg.ro/index.php/studiaeconomia. Pages $64-79$ 
Omodero, C.O., (2019)

The consequences of shadow economy and corruption on tax revenue performance in Nigeria

and it gives an estimate of the size of the shadow economy. However, it is extremely very important to be fully aware of the causes of the informal sector activities, their methods of operation and ways to prevent the duplicitous efforts to evade tax. This is necessary because accounting information might be inaccurate to some extent and the micro and macroeconomic tendency to show gross image of available resources in a fraudulent manner (Opreț, Turcaș, Dumiter \& Brezeanu, 2017) might not be detected in a tax audit.

\subsubsection{Indirect approach}

The indirect approaches identified by (Schneider \& Enste, 2000) include: national accounting statistics approach, transaction approach, currency demand approach, electricity consumption approach and Multiple Indicators, Multiple Causes (MIMIC) approach established by (Vuletin, 2008; Schneider, 2010; Abdih \& Medina, 2016). For the purpose of this study, three relevant indirect approaches have been selected and they are: the transaction approach, currency demand approach and MIMIC approach.

\subsubsection{Transaction approach}

The transaction approach uses data gathered on the overall transactions in the economy which represent both the official and unofficial Nominal GDP, thus the estimated size of the shadow economy is subtracted from the total Nominal GDP. In Nigeria, the Nominal GDP consists of contributions from both official activities and unofficial activities (shadow economy). In 2017, informal economy contributed about $65 \%$ of the Nigeria's Nominal GDP (IMF, 2017) and the bulk of it is derived from the agricultural sector. This study uses the estimated size of the shadow economy expressed as percentage of total Nominal GDP for the period under study. Appendix 1 below shows that the growth of shadow economy in Nigeria has been increasing at an alarming rate since 2016 confirming the IMF (2017) submission that informal sector is contributing to the economy more than the formal sector. However, despite the input of the shadow economy, the fact is that the income from the informal sector is usually unreported and so the government loses substantial income that would have been earned through tax revenue.

\subsubsection{Currency demand approach}

Currency demand approach is based on the assumption that shadow transactions are undertaken with cash in order to avoid leaving a proof that could be traceable by the authorities (Tanzi, 1980; 1983; 1999; Feige and Urban, 2008). This is the height of corruption and the reason why it is believed that shadow economy and corruption are interconnected because they work together. Where there are 
Omodero, C.O., (2019)

The consequences of shadow economy and corruption on tax revenue performance in Nigeria

informal activities, corruption is present with all its features because all the people that will help to conceal the cash transactions must have received their own share of the bribe in order to close their mouths. If there is no one to disclose the cash transactions that have taken place, even the tax audit cannot reveal it since there are no records, receipts or even third party evidences.

\subsubsection{MIMIC approach}

Multiple Indicator Multiple Cause (MIMIC) approach takes into consideration the numerous causes of shadow economy as well as the several influences of the informal economy on other areas of the economy. This approach uses both the visible and the discreet variables causing shadow economy and the resultant effects of the informal sector (Abdih \& Medina, 2016, Schneider, 2010, Vuletin, 2009). The figure 1 below gives a pictorial illustration of factors causing shadow economy in Nigeria and the effects of the informal sector in the country. From figure 1 below, the MIMIC approach depicts that tax liability, regulatory burden, unemployment rate, corruption and self-employment are major determinants of shadow economy in the country which in turn boosts Nominal GDP growth, gives the public an opportunity to withhold unreported income and causes tax revenue losses for the government. Informal economy output that could be taxable income is considered as tax revenue loss because the informal sector participants or agents equally benefit from the public goods and services provided by the government through tax revenues received from the loyal citizens (Anwar, Akbar, Akbar, \& Azhar, 2017).

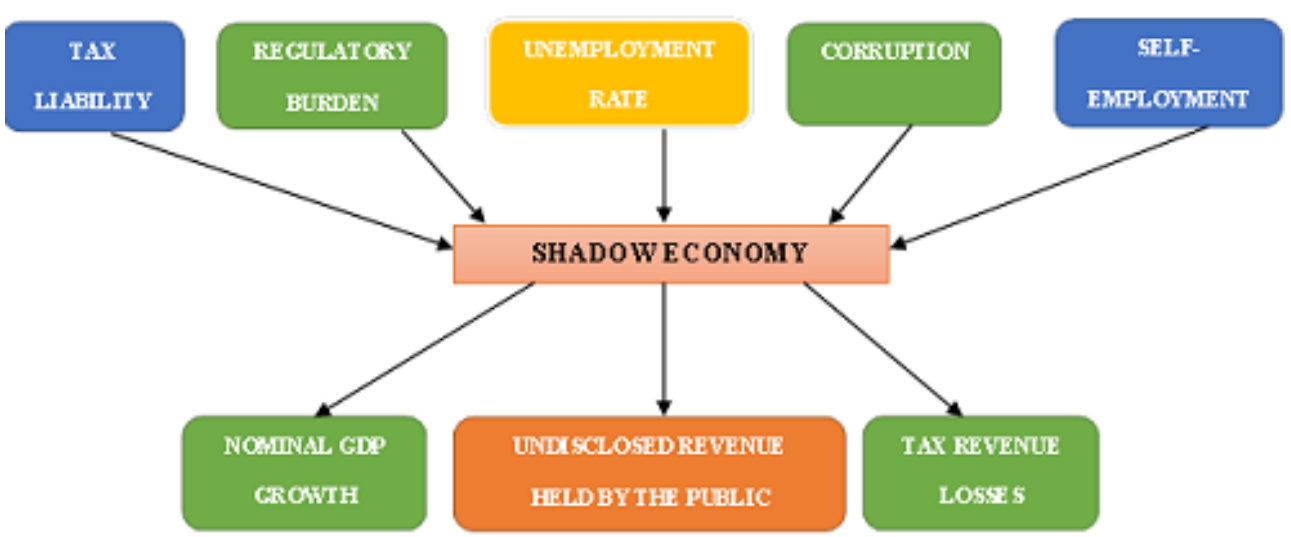

Figure 1 MIMIC approach of measuring shadow economy Source: Author's Desk Research, 2019 
Omodero, C.O., (2019)

The consequences of shadow economy and corruption on tax revenue performance in Nigeria

Some of the variables in figure 1 above are quantifiable, for instance the Nominal GDP, while others are simply qualitative in nature and can only be felt. Examples are the regulatory burden and corruption, although the Transparency International came up with an index called corruption perception index which presently helps to determine the level of corrupt activities prevailing in almost all the countries in the world.

\subsection{Empirical review}

Tedika and Mutascu (2013) studied the effects of shadow economy on tax revenues of several African Countries using panel-model approach. The data employed for the study covered a period from 1999 to 2007 and the findings revealed that shadow economy had a significant negative impact on tax revenues of the selected African Countries. The study suggested that African governments should endeavor to manage shadow economy occurrences to avoid subsequent decreases in the level of tax revenue. Tatariyanto (2014) used Multiple Indicator and Multiple Cause (MIMIC) approach to examine the size of underground economy and loss of tax revenue in Indonesia from 2000 to 2008. The study found evidence that underground economy increased when large number of people were not submitting tax returns due to changes in tax policy and growth in the rate of unemployment. The study also revealed that underground economy in Indonesia decreased sequel to a greater public awareness to comply with tax payment as part of their civic obligations. Muchiri (2014) took into consideration the inability of tax revenue to meet the expenditure requirements of the government in Kenya due to the existence of shadow economy even when several reforms in taxation have been implemented. The study made use of ordinary least squares (OLS) method and secondary form of data, thus the result showed that an increase in the size of the informal sector leads to a decrease in revenue performance and vice versa, which is quantitatively significant. The study also found that the key factors determining tax revenue performance in Kenya include foreign direct investment, per capita GDP and openness to trade. The study suggested formulation of policies that would include informal sector in the tax bracket which should involve fostering of voluntary tax compliance and reduction of tax collection costs.

Barbara and Claudio (2015) applied simulation-based analysis to assess the effects of several tax reforms in the economy of Italy due to the challenge of tax evasions resulting from undeclared jobs and businesses. The researchers constructed various tax reform models and came up with several results which revealed that macroeconomic and welfare effects of tax reforms might be grievously underestimated if shadow economy were to be overlooked. Also, deducting the cost of labor from the business tax base would be an overstatement and could be detrimental to the size of the shadow economy. Further findings showed that 
Omodero, C.O., (2019)

The consequences of shadow economy and corruption on tax revenue performance in Nigeria

shadow economy could be decreased permanently through variations in the tax mix which could also reduce the labor tax. Hunady and Orviska (2015) evaluated the effect of corruption on tax revenue in 46 OECD and Latin America Countries using data that covered a period from 1998 - 2013. The study employed fixed and random effect models and the results indicated that corruption had a significant negative effect on total tax revenue. Further assessment was carried out using the tax revenue, the study also found strong evidence that corruption impacted more negatively on taxes from goods and services. Shahab, Pajooyan and Ghaffari (2015) used 25 countries including both developed and developing countries to examine the effect of corruption on shadow economy from 1999 - 2007. The study found evidence that the relationship between corruption and shadow economy varied according to the level of corruption prevailing in each country.

Gaspareniene et al. (2016) reviewed the impact of shadow economy determinants on the size of shadow economy in Ukraine from 2005 - 2012. The study revealed that 99 percent of shadow economy in Ukraine was determined by variables such as tax rate, overall employment rate, import of goods and services, GDP and participation of working age people in the labor market. In trying to explore the factors that cause the existence of shadow economy in countries, Hassan and Schneider (2016) applied MIMIC approach to investigate the size and development of the shadow economies of 157 countries from 1999 to 2013, the study found evidence that higher tax, unemployment rates and regulatory burdens were the major determinants of the shadow economy. The findings further disclosed that from 1999 to 2013, informal economy accounted for 33.77\% of official GDP of 157 countries which comprised high income OECD countries, Central Asian Eastern European and also the developing countries. Mawejje and Munyambonera (2016) employed quarterly data from 1999 to 2013 and ARDL bounds testing techniques to investigate the determinants of tax revenue performance in Uganda. The results indicated that the shadow economy and agricultural sector had the largest impediments to tax revenue performance while trade openness, development expenditures and industrial sector growth had positive relationship with tax revenue performance.

Nchor and Konderla (2016) used currency demand approach to investigate the size of the shadow economy of Czech Republic and the attributable losses in tax revenue. The approach helped to measure two stages of shadow economy which included the econometric estimation of an aggregate money demand and the calculation of the value through the quantity theory of money. The study found that the shadow economy of Czech Republic on the average was about $20.9 \%$ as at the end of 2013 and that the country loses an average of tax revenue of about $7.2 \%$ of GDP annually. Borlea et al. (2017) investigated the impact of corruption and shadow economy on economic growth of the European Union Countries from 2005

70 S sciendo Studia Universitatis "Vasile Goldis" Arad. Economics Series Vol 29 Issue 3/2019 ISSN: 1584-2339; (online) ISSN: $2285-3065$

Web: publicatii.uvvg.ro/index.php/studiaeconomia. Pages $64-79$ 
Omodero, C.O., (2019)

The consequences of shadow economy and corruption on tax revenue performance in Nigeria

to 2014. The findings indicated that corruption and shadow economy had a very strong correlation and both of them collectively influenced economic growth of the European Countries significantly and negatively. Peter (2017) examined the impact of shadow economy on tax revenue performance in Zimbabwe using ordinary least squares (OLS) method and annual time series data from 1980 to 2015. The regression results indicated among others that shadow economy had a positive and significant impact on tax revenue. The finding of Peter (2017) is not in line with the concept of shadow economy which is known for concealing income to evade tax, and if business and personal incomes are not disclosed in order for authorities to charge tax, how then can shadow economy have a significant positive impact on tax revenue. In other words, it is assumed that some form of taxes in Zimbabwe are gotten through shadow economy for it to have positive influence on tax revenue.

Awasthi and Engelschalk (2018) considered the relationship between taxation and the shadow economy and how the tax system can stimulate and enforce the formalization of business activities. The study found the existence of strong negative relationship between tax revenue collection and the informal economy. The findings further indicated that measures to get informal economy into paying tax must be holistic and involve some form of traditional approach of monitoring and use of law enforcement tools which may require tax officials gaining access into the data base of the informal economy participants, including third information from various public and private sources as well as banks. Guillermo and Deyvi (2018) studied the impact of informal economy on tax revenues and economic growth using a panel data of OECD members and Latin America countries from 1995 to 2016. The study made use of a MIMIC approach and Generalized Moment Method (GMM) in order to establish the impact of the size of the informal economy on economic growth and tax revenue collection. The findings revealed that the estimated average size of the informal economy as a percentage of the GDP for Latin America Countries was 34\% while, in the case of the OECD countries, it was $19.83 \%$. From the results, the country with the largest size of unofficial economy in Latin America was Peru, with a size of $37.4 \%$ of the GDP for 2016 while for OECD countries, Turkey had the highest unofficial economy with a size of $29.75 \%$ of the GDP for 2016 . The results also indicated that the Latin America country with the smallest size of informal economy was Uruguay with $14.47 \%$ while that of OECD was Denmark with $12.84 \%$, both for 2016. However, the study generally found that for both Latin America and OECD countries, the informal economy had a negative impact on the amount of tax revenue collected by the government. 
Omodero, C.O., (2019)

The consequences of shadow economy and corruption on tax revenue performance in Nigeria

\subsection{Research gap}

This present study is organized to show the impact of shadow economy and corruption on tax revenue performance in Nigeria from 1996 to 2018. The size of shadow economy employed is the percentage of the Nominal GDP representing the contribution from the informal sector and the rate of corruption is applied instead of the corruption perception index (CPI) values. Although other unquantifiable variables determining shadow economy and invariably contributing to tax revenue losses are considered in theory, however, the major aim is to empirically determine the effect of shadow economy and corruption on tax revenue generated in Nigeria.

\section{Methodology}

\subsection{Research Design}

This research employed a quasi-experimental design in order to achieve the objectives of the study. Here the research adopted the econometric analysis techniques of ordinary least squares (OLS) multiple regression technique. This research design is required because the designated research area for examination is analytical, empirical and quantitative in nature where the dependent and independent variables are observed over a time period for any deviation that can feasibly arise.

\subsection{Types and Sources of Data Collection}

The study made use of secondary form of data because the purpose of this research is to produce an empirical evidence in this area of study. Time series data relating to the dependent and predictor variables employed in this study covered a period from 1996 to 2018. The shadow economy is a percentage of the Nominal GDP of Nigeria while the rate of corruption is the value obtained after grossing up the corruption perception index (CPI) applicable to Nigeria by 100 and subtracting the value from 100. The reason is that CPI value represents the degree of freedom from corruption and it is divided by 10 , and when the same value is multiplied by 100 , it can be subtracted from 100 to arrive at the rate of corruption prevailing in a particular country. The tax revenue is expressed in billions of Naira (local currency), thus to achieve uniformity due to discrepancy of the values, all the data have been expressed in their logarithm form. The level of significance chosen for this study is $5 \%$, thus the individual result of the variables will be significant at $5 \%$. All the data employed in this study were obtained from the Central Bank of Nigeria Statistical Bulletin, International Monetary Fund and Transparency International.

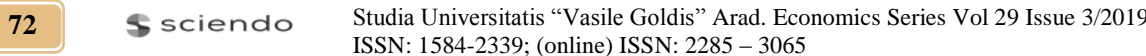

Web: publicatii.uvvg.ro/index.php/studiaeconomia. Pages $64-79$ 
Omodero, C.O., (2019)

The consequences of shadow economy and corruption on tax revenue performance in Nigeria

\subsection{Model Specification}

The functional and econometric relationship between the response variable and the predictor variables are seen in the equation below:

$\mathrm{TRV}=\mathrm{f}(\mathrm{SWY}, \mathrm{ROC})$

LOGTRV $=\beta_{0}+\beta_{1}$ LOGSWY $+\beta_{2}$ LOGROC $+\mu$

Where: TRV $=$ Tax revenue; SWY $=$ Shadow economy; $\mathrm{ROC}=$ Rate of corruption; $\beta_{0}=$ Constant; $\beta_{1}-\beta_{2}=$ Regression coefficients; $\mu=$ Error term.

On the a priori, we expect; $\beta_{1}<0, \beta_{2}<0$.

\section{Data analysis and interpretations}

Table 1: Model Summary of results

\begin{tabular}{|c|c|c|c|c|c|}
\hline Model & R & R Square & Adjusted R Square & Std. Error of the Estimate & Durbin-Watson \\
\hline 1 & .825 & .681 & .649 & .29230 & 1.028 \\
\hline
\end{tabular}

a. Predictors: (Constant), LOGROC, LOGSWY

b. Dependent Variable: LOGTRV

Source: Author's computation, 2019

From table 1 above, the correlation (R) value is $82.5 \%$ which implies that the association between tax revenue and the predictor variables is very strong. The coefficient of determination has a value of $68.1 \%$ signifying that corruption and shadow economy explain up to $68.1 \%$ of the changes in tax revenue while the balance of $31.9 \%$ applies to other variables that were not used in the study. The Durbin-Watson of 1.03 is within the limit that does not give room for concern.

Table 2: ANOVA

\begin{tabular}{|cc|c|c|c|c|c|}
\hline \multicolumn{2}{|c|}{ Model } & Sum of Squares & Df & Mean Square & F & Sig. \\
\hline \multirow{4}{*}{1} & Regression & 3.652 & 2 & 1.826 & 21.374 & .000 \\
& Residual & 1.709 & 20 & .085 & & \\
& Total & 5.361 & 22 & & & \\
\hline
\end{tabular}

a. Dependent Variable: LOGTRV

b. Predictors: (Constant), LOGROC, LOGSWY

Source: Author's computation, 2019

Table 2 above gives the regression result on F-statistic. The value is 21.374 while the p-value is $0.000<0.05$ level of significance. The result shows that the model is statistically significant and suitable for the study. However, the result simply implies that shadow economy and corruption jointly influence tax revenue 
Omodero, C.O., (2019)

The consequences of shadow economy and corruption on tax revenue performance in Nigeria

performance significantly. This confirms the assertions that shadow economy and corruption are unified forces that exist simultaneously in an economy and have the capacity to mar an economic system, cause tax revenue losses and concurrently deny the masses the opportunity of benefiting from government provision of public goods and services.

Table 3: Regression Coefficients

\begin{tabular}{|cc|c|c|c|c|c|}
\hline \multirow{2}{*}{ Model } & \multicolumn{2}{|c|}{$\begin{array}{c}\text { Unstandardized } \\
\text { Coefficients }\end{array}$} & $\begin{array}{c}\text { Standardized } \\
\text { Coefficients }\end{array}$ & \multirow{2}{*}{ Sig. } \\
\cline { 3 - 5 } & B & Std. Error & Beta & & \\
\hline \multirow{2}{*}{1} & (Constant) & 27.322 & 3.888 & & 7.026 & .000 \\
& LOGSWY & -1.574 & 1.943 & -.115 & -.810 & .427 \\
& LOGROC & -11.372 & 2.103 & -.767 & -5.407 & .000 \\
\hline
\end{tabular}

a. Dependent Variable: LOGTRV

Source: Author's computation, 2019

Table 3 shows the regression results of all the independent variables. The result depicts that shadow economy (LOGSWY) t-statistic value is -0.810 and the p-value is $0.427>0.05$. So, Hol is accepted and the alternative declined. This result reveals that shadow economy has a negative impact on the tax revenue, but the effect is not significant as revealed in the studies of (Tedika \& Mutascu, 2013; Nchor \& Konderla, 2016; Borlea et al., 2017; Guillermo \& Deyvi, 2018). However, the result contradicts the findings of Peter (2017) which established that shadow economy had a significant positive impact on tax revenue in Zimbabwe.

On the other hand, the t-statistic for rate of corruption is -5.407 with the $p$-value of $0.000<0.05$ significance level. This is a clear evidence that corruption has a significant negative influence on tax revenue performance in Nigeria. Thus, Ho2 is rejected and the alternative which states otherwise accepted. This result is in agreement with the findings of (Hunady \& Orviska, 2015; Borlea et al., 2017) among others.

\section{Conclusion and recommendations}

\subsection{Conclusion}

The results of the study have revealed that both shadow economy and corruption go with negative influences on tax revenue performance in Nigeria. Apart from corruption, several factors have been detected as the major determinants of shadow economy in Nigeria, for instance the high rate of unemployment, self-employment, tax burdens and regulatory burdens. These are common determinants of the informal sector in Nigeria and the concern is that, they all lead to tax revenue

74 Sciendo Studia Universitatis "Vasile Goldis" Arad. Economics Series Vol 29 Issue 3/2019 ISSN: 1584-2339; (online) ISSN: $2285-3065$

Web: publicatii.uvvg.ro/index.php/studiaeconomia. Pages $64-79$ 
Omodero, C.O., (2019)

The consequences of shadow economy and corruption on tax revenue performance in Nigeria

losses since the income derived from the informal economy is not disclosed due to its 'cash and carry deal type'. The implication is that as the government losses revenue through shadow economy and corruption, it give room for insufficient provision of public goods and services. In other words, the government will be handicap and will fail to perform its duties to the public. That means, the expectation of the public from the government will not be met due to insufficient fund occasioned by revenue leakages through tax evasions. Although shadow economy leads to growth in the Nominal GDP, but the effect on tax revenue is not favorable to the government.

\subsection{Recommendations}

1. The study is recommending that the root cause of shadow economy in Nigeria should be addressed in order to reduce the size. Factors such as unemployment, strict tax burdens, the cost of formalization of business and other regulatory burdens should be moderated in the favour of the common citizens of the country.

2. The business environment should be less hostile for businesses to stop hiding their activities and keeping operating behind the back doors. The government can reduce tax burdens through friendly awareness of what the taxpayer stand to gain by complying with tax payment and by ensuring that basic goods and services are provided for the citizens. When the benefit for paying tax are known and physically felt, citizens will willingly disclose their income.

3. In addition, when official jobs are available, those employed cannot hide their income because taxes are deducted at source and remitted to the government accordingly. Therefore, the study is suggesting that the government should make jobs available for the citizens in order to reduce the size of the shadow economy in the country.

4. There is need for the government to take the fight against corruption to a higher level. Efforts should be made to study and emulate the manner and style some less corrupt advanced countries fought it and today corruption cannot gain ground in those countries. Corruption gives more boost to shadow economy and should be strictly addressed to restore the confidence the tax payers have lost seeing corruption eating too deep even among those that represent the government.

\section{Acknowledgements}

The author thanks the anonymous reviewers and editors of Studia Universitatis "Vasile Goldis" Arad, Economic Series for their valuable contribution.

\section{Funding}

This research received no specific grant from any funding agency in the public, commercial, or not - for - profit sectors. 
Omodero, C.O., (2019)

The consequences of shadow economy and corruption on tax revenue performance in Nigeria

\section{Author's Contributions}

The author conceived the study, did the literature review section and was responsible for the design, data collection, data analysis and interpretation.

\section{Disclosure Statement}

The author does not have any conflicting financial, professional, or personal interests from other parties.

\section{References}

1. Abdih, Y., \& Medina, L., (2016), The informal economy in the Caucasus and Central Asia: Size and determinants, In Arnis Sauka, Friedrich Schneider and Colin C. Williams (Editors), Entrepreneurship and the Shadow Economy, Edward Elgar Publishing Inc.

2. Anwar, S., Akbar, R., Akbar, M.W. \& Azhar, A., (2017), Measuring the size of underground Economy in Pakistan: A microeconomic approach, Journal of Applied Environmental and Biological Sciences, 7(8), pp. 84-93.

3. Aruoba, S.B., (2010), Informal Sector, Government Policy and Institutions, 2010 Meeting Papers, 324, Society for Economic Dynamics.

4. Awasthi, R. \& Engelschalk, M., (2018), Taxation and the shadow economy. How the tax system can stimulate and enforce the formalization of business activities, Policy Research Working Paper 8391, World Bank Group Governance Global Practice.

5. Barbara, A. \& Claudio, C., (2015), Tax reforms and the underground economy: a simulation-based analysis, Dipartimento di Economia, Diritto e Istituzioni, Universita degli Studi di Roma Tor Vergata, Via Columbia 2, 00133 Rome, Italy.

6. Bird, R., Martinez-Vasquez, J., \& Torgler, B., (2008), Tax effort in developing countries and high income countries: The impact of corruption, Voice Accountability, Economic Analysis and Policy.

7. Bologna, J., (2015), The effect of informal employment and corruption on income levels in Brazil, Journal of Comparative Economics, Elsevier, 44(3), pp. 657-695.

8. Borlea, S.N., Achim, M.V. \& Miron, M.G.A., (2017), Corruption, shadow economy and economic growth: an empirical survey across the European Union countries, Studia Universitatis "Vasile Goldis" Arad, Economic Series, 27(2), pp. 19-32.

9. Chen, H. \& Schneider, F., (2018), Size and causes of shadow economy in China over 1978-2016: based on the currency demand method, Retrieved on 06.04.2019 from:

www.econ.jku.at/t3/.../schneider/.../Chen_Schneider_2018_Sizeandcausesofshado w.p

76 Sciendo Studia Universitatis "Vasile Goldis" Arad. Economics Series Vol 29 Issue 3/2019 ISSN: 1584-2339; (online) ISSN: $2285-3065$

Web: publicatii.uvvg.ro/index.php/studiaeconomia. Pages $64-79$ 
Omodero, C.O., (2019)

The consequences of shadow economy and corruption on tax revenue performance in Nigeria

10. Feige, E.L. \& Urban, I., (2008), Measuring Underground (Unobserved, NonObserved, Unrecorded) Economies in Transition Countries: Can We Trust GDP? Michigan: The William Davidson Institute.

11. Gaspareniene, L., Remeikiene, R. \& Heikkila, M., (2016), Evaluation of the impact of shadow economy determinants: Ukrainian case, Intellectual Economics, 10(2016), pp. 108-113.

12. Guillermo, R.B.C. \& Deyvi, A.A., (2018), The informal economy and its impact on tax revenues and economic growth, Analysis of OECD members and Latin America Countries (1995-2016). Retrieved on 20.03.2019 from:

https://www.researchgate.net/publication/328343445.

13. Hassan, M., (2017), The impact of the shadow economy on aid and economic development nexus in Egypt, Munich Personal RePEc Archive, Available online at: https://mpra.ub.uni-muenchen.de/80990/.

14. Hunady, J. \& Orviska, M., (2015), The effect of corruption on tax revenue in OECD and Latin America countries, Retrieved on 22.03.2019 from:

https://www.researchgate.net/publication/279188559

15. International Monetary Fund, (2017), Nigeria's informal economy accounts for $65 \%$ of GDP - IMF, Retrieved on 20.03.2019 from:

https://www.businessamlive.com/nigerias-informal-economy-accounts-65-gdpimf/

16. Ivanyna, M., Moumouras, A. \& Rangazas, P. C. (2016), The culture of corruption, tax evasion, and economic growth (January 2016), Economic Inquiry, 54(1), pp. 520-542.

17. Mawejje, J. \& Munyambonera, E.F., (2016), Tax revenue effects of sectoral growth and public expenditure in Uganda, Economic Policy Research Centre, Research Series, No. 125.

18. Muchiri, K.B., (2014), An analysis of the effect of the growth of the informal sector on tax revenue performance in Kenya, Msc. Thesis submitted to the school of Economics, University of Nairobi.

19. Nchor, D. \& Konderla, T., (2016), The Shadow Economy of Czech Republic and Tax Evasion: The Currency Demand Approach, Acta Universitatis Agriculturae et Silviculturae Mendelianae Brunensis, 64(6), 2081-2086.

20. Ogunc, F. \& Yilmaz, G., (2000), Estimating the Underground Economy in Turkey, The Central Bank of the Republic of Turkey, Research Department, Discussion paper, September, 2000.

21. Opret, L.A., Turcaş, F.M., Dumiter, F.C. \& Brezeanu, P., (2017), Tax evasion between fraud and Legality, Studia Universitatis "Vasile Goldis" Arad, Economic Series, 27(4), pp. 1-11.

22. Peter, L., (2017), Investigating the impact of the shadow economy on tax revenue performance in Zimbabwe (1980-2015), Bsc. Project submitted to 
Omodero, C.O., (2019)

The consequences of shadow economy and corruption on tax revenue performance in Nigeria

Department of Economics, Faculty of Commerce, Midlands State University, Gweru, Zimbabwe.

23. Petrescu, I.M., (2016), The Effects of Economic Sanctions on the Informal Economy, Management Dynamics in the Knowledge Economy, 4(4), pp. 623-648.

24. Putnins, T.J. \& Sauka, A., (2014), Measuring the Shadow Economy Using Company Managers, Journal of Comparative Economics, Forthcoming, Available at SSRN https://ssrn.com/abstract=2423253.

25. Schneider, F., (2010), The influence of public institutions on the shadow economy: An empirical investigation for OECD Countries, European Journal of Law and Economics, 6(3), pp. 441-468.

26. Schneider, F., \& Enste, D., (2000), Shadow economies: size, causes and consequences, The Journal of Economic Literature, 38(1), pp. 77-114.

27. Shahab, M.R., Pajooyan, J. \& Ghaffari, F, (2015), The effect of corruption on shadow economy: an empirical analysis based on panel data, International Journal of Business and Development Studies, 7(1), pp. 85-100.

28. Tanzi, V., (1980), The underground economy in the United States: estimates and implications, Banca Nazionale del Lavoro, 135, pp. 427-453.

29. Tanzi, V., (1983), The underground economy in the United States: annual estimates, 1930-1980, IMF Staff Papers, 30, pp. 283-305.

30. Tanzi, V., (1999), Uses and Abuses of Estimates of the Underground Economy, Economic Journal, 109(3), pp. 338-347.

31. Tatariyanto, F., (2014), Taxing the underground economy: The case of Indonesia, Journal of Economics and Sustainable Development, 5(27), pp. 236250 .

32. Tedika, O. \& Mutascu, M., (2013), Shadow economy and tax revenue in Africa. Munich Personal RePEc Archive, Available on line at: http://mpra.ub.unimuenchen.de/508121.

33. Vuletin, G.J., (2008), Measuring the informal economy in Latin America and the Caribbean, International Monetary Fund, Working Paper No. 08/102.

78 S sciendo Studia Universitatis "Vasile Goldis" Arad. Economics Series Vol 29 Issue 3/2019 ISSN: 1584-2339; (online) ISSN: $2285-3065$

Web: publicatii.uvvg.ro/index.php/studiaeconomia. Pages $64-79$ 
Omodero, C.O., (2019)

The consequences of shadow economy and corruption on tax revenue performance in Nigeria

\section{Appendix 1}

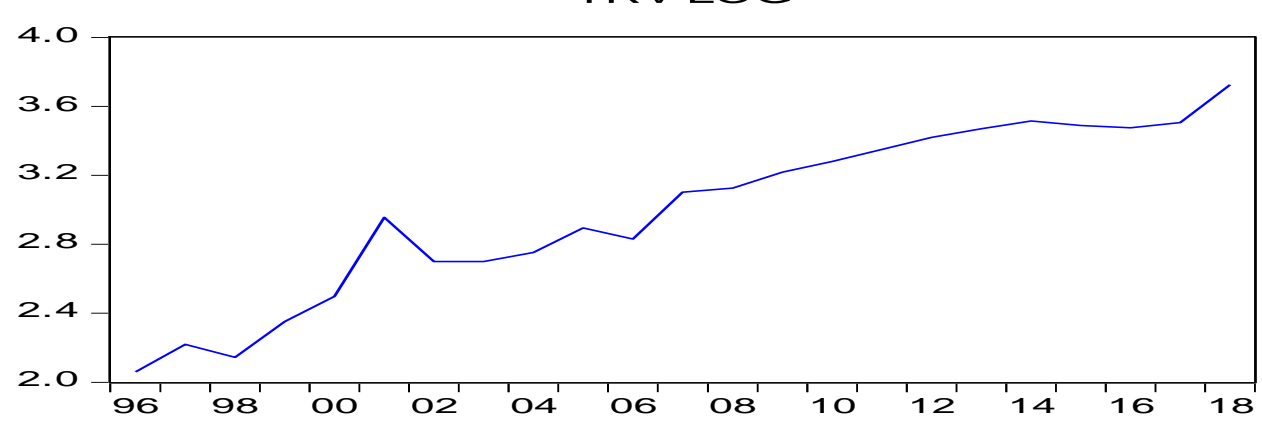

SWYLOG

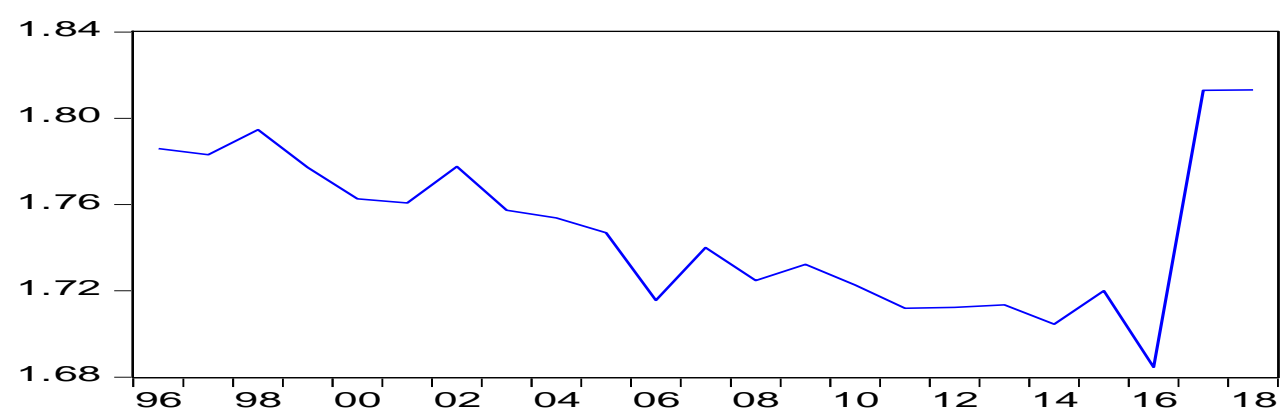

ROO LOG

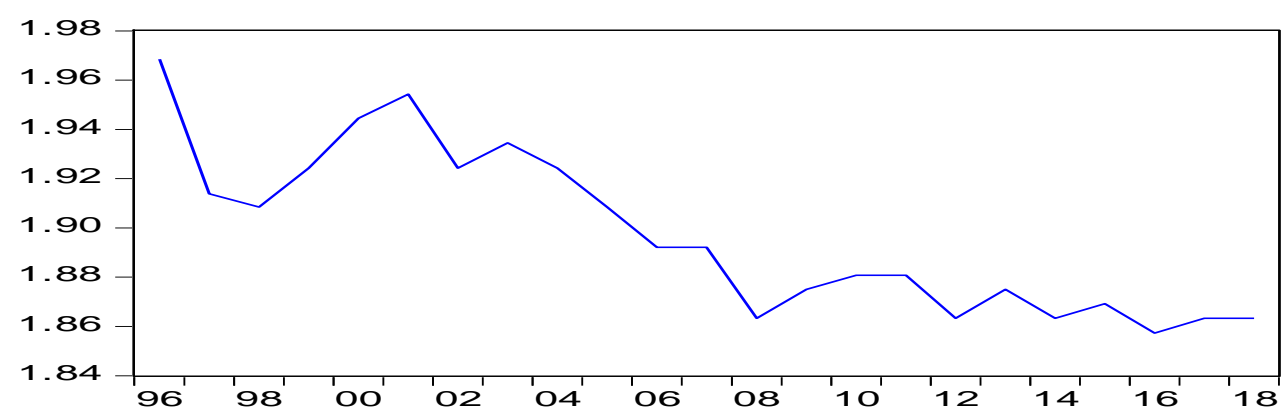

